\title{
\#5
}

\section{Idealisme Jurnalis TV vs Kepentingan Pemilik Media}

\author{
Dani Setiadarma
}

"Free Press? Press is free, for anyone who owns one!"

Kalimat ini diucapkan oleh Lowell Bergman, seorang produser berita yang diperankan oleh Al Pacino dalam film "The Insider" ketika manajemen stasiun televisi CBS melarang penayangan wawancara ekslusif seorang mantan petinggi perusahaan rokok dalam program berita "60 minutes". Alasan pelarangan disiarkannya kesaksian whistleblower yang membongkar adanya kandungan kimia berbahaya dalam rokok adalah adanya kemungkinan tuntutan hukum bernilai milyaran dolar terhadap CBS. Lowell kecewa Direktur Pemberitaan mendukung manajemen CBS dan mempertaruhkan kredibilitas program "60 minutes" yang dipertahankannya bersama tim redaksi selama 14 tahun. 
Film rilisan tahun 2000 yang diangkat dari kisah nyata ini masih relevan memberikan gambaran bagaimana tarik menarik kepentingan antara idealisme jurnalis dengan kepentingan pemilik media yang terjadi di sebuah redaksi pemberitaan televisi. Pengungkapan salah satu skandal kesehatan terbesar di Amerika Serikat tersebut dilarang tayang bukan karena isi berita tidak memenuhi nilai-nilai jurnalistik, tetapi karena adanya ancaman terhadap kepentingan finansial pemilik perusahaan. Proses pengambilan keputusan mengenai berita yang layak tayang di stasiun televisi bukanlah milik redaksi pemberitaan, namun merupakan hasil interaksi dari berbagai kepentingan. Pertanyaannya, apakah benturan antara dan pemiik perusahaan media massa menunjukkan bahwa tidak ada lagi kebebasan pers di redaksi pemberitaan televisi? Apakah kepentingan pemilik media massa telah menjadi kendali dalam praktik jurnalistik di media massa?

\section{Newsroom: Pertarungan Idealisme Jurnalis vs Kepentingan Pemilik Media}

Media massa merupakan elemen penting dalam kehidupan berdemokrasi sebagai pilar keempat demokrasi yang mengontrol kekuasaan dan memungkinkan masyarakat untuk menyampaikan pendapat dalam mengikuti jalannya pemerintahan. Indikator kehidupan media dan komunikasi yang demokratis adalah terdapatnya jaminan kebebasan berekspresi, kemerdekaan berbicara, dan kemerdekaan pers. Jika Lowell Bergman, produser berita "60 minutes" bisa berdebat dengan Kepala Pemberitaan CBS dengan menyindir "are you a businessman or a newsman?", tanpa harus terancam kehilangan pekerjaan, di Indonesia lain lagi ceritanya. Raymond Rondonuwu, produser berita "Seputar Indonesia" RCTI menerima peringatan keras karena mempertanyakan permintaan pemimpin redaksi untuk memuat berita tentang pertemuan anggota KPU dengan salah satu tim sukses calon presiden yang diduga membocorkan materi debat. 
Raymond menilai berita tersebut tidak jelas sumbernya sehingga tidak sesuai dengan prinsip jurnalistik. Namun Raymond justru langsung menerima Surat Peringatan Ketiga (SP3). Tak hanya Raymond, pertanyaan yang muncul di dalam kepala semua jurnalis televisi di semua stasiun televisi di Indonesia pada masa pemilihan presiden 2014 kepada Pemimpin Redaksi mereka adalah "are you a politician or a newsman?"

Di Indonesia, pada saat intervensi dan kontrol negara kepada media sudah jauh berkurang, represi terhadap jurnalis baik di lapangan maupun di ruang redaksi berita ternyata masih terjadi. Lembaga internasional yang bergerak di bidang advokasi jurnalis, Reporters Without Borders (RSF), mencatat salah satu bentuk represi dalam Indeks Kemerdekaan Pers Dunia pada tahun 2018 adalah adanya tekanan pemilik media pada redaksi berita. Dari 180 negara, peringkat kebebasan pers Indonesia menduduki posisi ke-124. Kebebasan pers di Indonesia sebenarnya telah menemukan momentumnya melalui reformasi 1998, setelah terkekang selama 32 tahun di masa pemerintahan Soeharto. Undang-Undang No. 32 tahun 2002 tentang penyiaran dan Undang-Undang No. 40 tahun 1999 tentang pers juga membuka peluang baru di bisnis media penyiaran dengan harapan akan semakin meningkatkan praktek jurnalistik yang independen. Sejumlah pengusaha muncul menjadi pemain baru dalam bisnis penyiaran televisi yang sebelumnya hanya dikuasai oleh keluarga Soeharto dan kroni-kroninya. Namun, dibukanya keran kebebasan dalam pengelelolaan media ini menimbulkan permasalahan baru, yakni konglomerasi media. Perkembangan bisnis televisi swasta yang semakin pesat ternyata hanya terpusat pada 12 kelompok bisnis saja, yakni MNC Group, Kompas Gramedia Group, Jawa Pos Group, Mahaka Media Group, Elang Mahkota Teknologi, CT Corp, Visi Asia Group, Media Group, MRA Media, Femina Group, Tempo Inti Media, dan Berita Satu Media Holding. Dalam hal kepemilikan media penyiaran televisi, MNC Group memiliki RCTI, Global TV dan MNC TV; Group Emtek 
menguasai SCTV, Indosiar dan Omni Channel TV; Visi Media Asia mengendalikan ANTV dan TV One; CT Corp memiliki TransTV dan Trans7 (Laksmi, 2012: 4).

Sejumlah pemilik media yang menguasai beberapa media sekaligus tersebut tergabung dalam partai politik yang ada di Indonesia, seperti Hary Tanoesudibjo (MNC) di Partai Perindo, Surya Paloh (Media Group) di Partai Nasional Demokrat, dan Aburizal Bakrie di Partai Golkar. Penguasaan media penyiaran televisi oleh segelintir pebisnis ini merugikan khalayak media karena sangat berpotensi untuk memunculkan adanya monopoli informasi dan intervensi terhadap ruang redaksi pemberitaan. Alihalih menciptakan demokratisasi informasi, konglomerasi media justru menghilangkan kebebasan pers. Pekerja media di stasiun TV, dalam hal ini para jurnalis seperti Raymond, seperti tak kuasa terhadap tekanan pemilik media dalam proses produksi berita dan dalam mengambil keputusan untuk menetapkan berita mana yang layak dan tidak layak dimuat dalam program berita (Haryanto, 2010).

Pertarungan antara idealisme jurnalis dengan pemilik media di ruang redaksi juga menjadi perhatian para peneliti di berbagai negara, diantaranya dalam Herman and Chomsky's Propaganda Model: Its Application on Electronic Media and Journalists in Pakistan. Penelitian Syed Irfan Ashraf dan Syed Hussain Shaheed Soherwordi (2016) di University of Peshawar menyebutkan ekonomi politik media tidak hanya memandang kekuasaan dari perspektif kepemilikan media saja tetapi juga menjelaskan bagaimana proses pengambilan keputusan di redaksi berita terjadi. Meliput peristiwa perang di kawasan konflik Pakistan bahkan tidak lepas dari tekanan pemilik media yang mengintervensi ruang redaksi. Misalnya, sebuah pesta perkawinan di Karachi lebih layak menjadi berita daripada demonstrasi yang memprotes pelarangan kaum wanita untuk bersekolah. Untuk menghindari tekanan sosial yang datang dari masyarakat, jurnalis menggunakan strategi lain, 
yakni dengan memuat berita yang ditolak oleh media ke halaman web pribadi.

Joshua J. Weikert (2013) melakukan analisis siaran berita malam NBC Nightly News dan artikel New York Times selama periode pemilihan umum pada tahun 1996, 2000, 2004, dan 2008 dalam disertasinyaBalancing Act: How An Unbalanced Media Affects The Electorate. Penelitian yang menggunakan metodologi kuantitatif dan analisis isi ini menemukan pembagian volume liputan kampanye dan persentase liputan yang tidak seimbang terhadap para kandidat dalam masa pemilihan umum. Media yang tidak berimbang dalam liputan memiliki efek kepada pemilih yang menonton atau membaca berita tersebut. Haley Devaney (2013) dari University of California dalam Perceptions Of Media Bias: Viewing The News Through Ideological Cues, memaparkan buktibukti bahwa terjadi bias media di MSNBC, FOX dan CNN, akibat campur tangan pemiliknya. Di sisi lain, perspektif individu tentang media yang bias mempengaruhi cara berpikir mereka tentang konten berita sehingga media tidak bisa efektif menginformasikan peristiwa kepada publik.

Hal yang sama terjadi di Malaysia pada pemilihan umum 2014 lalu, di mana terjadi bias pemberitaan surat kabar karena kepentingan politik pemiliknya. Penelitian Azizuddin Sani (2014) dari University of Wollongong, Australia, yang dimuat dalam Asia Pacific Media Educator berjudul Malaysia's 13th General Election, Political Partisanship in the Mainstream Print Media, menemukan hampir semua media arus utama bias terhadap koalisi yang berkuasa, Barisan Nasional. Bias terhadap partai politik dalam koalisi yang berkuasa dikaitkan dengan kepemilikan surat kabar arus utama oleh kepentingan politik yang selaras dengan pemerintah Malaysia saat ini. Fokus penelitian ini adalah orientasi politik media arus utama dan pers lokal dalam liputannya pada pemilu ke-13 di Malaysia, serta efektiftas partai politik mendominasi liputan media. 


\section{Pemberitaan Kampanye 2014: Alat Politik Pemilik Media?}

Menarik untuk membahas pemberitaan kampanye di stasiun televisi swasta ketika kita membicarakan mengenai idealisme jurnalis dan kepentingan pemilik media di Indonesia. Pemberitaan kampanye pemilihan presiden menjadi penting dalam pelaksanaan sistem demokrasi langsung yang melibatkan partisipasi publik secara luas dalam setiap pemilihan presiden dan wakil presiden di Indonesia. Dalam sistem demokrasi, sebelum pemilihan presiden berlangsung terdapat proses kampanye dari para kandidat sebagai salah satu tahapan penting pemilu untuk meneguhkan dukungan dari calon masayarakat pemilih. Selama masa kampanye pemilihan presiden pada tanggal 4 Juni hingga 5 Juli 2014, dua pasangan kandidat yang bertarung adalah calon presiden dan wakil presiden Joko Widodo-Jusuf Kalla (Jokowi-JK) dan Prabowo-Hatta Rajasa. Keberimbangan informasi dan keadilan representasi adalah syarat bagi terwujudnya ide media massa sebagai ruang publik. Namun pada kenyataannya, pada tahun 2014 sejumlah redaksi pemberitaan televisi tampak tidak independen akibat tekanan pemilik media yang sekaligus juga menjadi politisi.

Bagaimana jika kita menelisik lebih jauh tekanan yang dihadapi Produser "Seputar Indonesia" RCTI Raymond Rondonuwu dengan mengambil studi kasus pemberitaan pada masa kampanye Pilpres 2014 untuk mengetahui sejauh mana pertarungan idealisme jurnalis RCTI dengan pemilik media? Berita "Dugaan Pembocoran Materi Debat Capres", yang dipertanyakan Raymond mengambil materi dari sumber polemik yang tidak bisa dipertanggung jawabkan kredibilitas dan validitasnya, yakni akun Twitter @triomacan2000. Bagaimana dengan pemberitaan lainnya seputar pemilu selama masa kampanye di RCTI?

Dalam pemberitaan Kampanye Pemilihan Presiden Republik Indonesia 2014 selama periode waktu tanggal 4 Juni hingga 5 Juli 
2014, selain berita mengenai dugaan bocornya materi debat ke kubu Jokowi, 'Seputar Indonesia" terkesan memberi penonjolan dan menokohkan Prabowo-Hatta dibandingkan dengan Jokowi-JK. Dari keseleruhan berita yang tayang sepanjang masa kampanye, sedikitnya ada 8 berita 'Seputar Indonesia' yang berhubungan dengan wacana ideologi dalam tiga tema besar. Pertama, adalah tema tentang konstruksi teks yang menunjukkan keunggulan Prabowo daripada Jokowi, baik secara pribadi maupun sebagai pasangan Capres-Cawapres. Kedua, adalah tema tentang konstruksi teks atas preferensi publik terhadap Prabowo berdasarkan hasil penelitian lembaga survei dan di media sosial. Ketiga adalah konstruksi teks dimana pernyataan Wiranto mengenai Prabowo terkait kasus penculikan aktivis dan kerusuhan Mei 1998 justru menjadi keuntungan buat Prabowo karena dianggap sebagai pihak yang dirugikan.

Tema tentang konstruksi teks yang menunjukkan keunggulan Prabowo daripada Jokowi, baik secara pribadi maupun sebagai pasangan Capres-Cawapres dapat dilihat pada berita berjudul "Prabowo Bicara" edisi 4 Juni 2014, Prabowo diwawancara khusus di kediamannya yang memiliki sejumlah peternakan. Prabowo selama sekitar empat menit berbicara mengenai potensi peternakan dan pertanian di Indonesia sambil menyampaikan visi di bidang ekonomi mengenai Indonesia yang harus kembali menjadi macan Asia. Pada 5 Juli 2014 berita berjudul "Presiden Pilihan Indonesia". Seputar Indonesia mengarahkan opini khalayak bahwa Prabowo lebih unggul dari Jokowi dan mendapat dukungan dari Presiden Susilo Bambang Yudhoyono bersama tujuh partai pendukung Koalisi Merah Putih lainnya. Sebagaimana lazimnya dalam setiap kontestasi, semua peserta berlomba untuk menjadi juara/pemenang. Masih pada edisi 5 Juli 2014, berita Seputar Indonesia dengan judul "Partai Demokrat Dukung Prabowo" merupakan penegasan terhadap konstruksi teks dengan tema keunggulan Prabowo. Penegasan ini tampak pada teks: "Visi misi 
capres Prabowo sejalan dengan Partai Demokrat dalam program ekonomi dan kesejahteraan rakyat".

Pada edisi 5 Juli 2014, dalam berita berjudul "Dukung Prabowo Hatta", Seputar Indonesia semakin memperkuat konstruksi teks pada berita sebelumnya yang menunjukkan keunggulan Prabowo dibandingkan Jokowi dengan menampilkan dukungan mahasiswa Jaringan Mahasiswa Indonesia dari 20 universitas di Indonesia terhadap pasangan Prabowo Hatta. Konstruksi pemberitaan Seputar Indonesia semakin menegaskan makna bahwa kepentingan pemberitaan diarahkan pada penegasan keunggulan figur Prabowo sebagai yang layak menjadi pemimpin Indonesia melalui Pilpres 2014. Artinya, makna ini menunjukkan keberpihakan yang sangat kuat bagi Seputar Indonesia terhadap Capres Prabowo.

Dalam tema tentang konstruksi teks atas preferensi publik terhadap Prabowo berdasarkan hasil penelitian lembaga survei dan di media social, praktik wacana dengan tujuan mengonstruksi realitas yang dilakukan ini merujuk pendapat Hamad, bahwa dalam mengkonstruksikan realitas, media memanfaatkan tiga komponen: (1) Pemakaian simbol-simbol politik (language of politic), (2) Strategi pengemasan pesan (framing strategies), dan (3) Kesediaan media memberi tempat (agenda setting function). Ketiganya itulah yang menentukan opini yang terbentuk (Hamad, 1999).

Edisi 4 Juni 2014, “Seputar Indonesia” menampilkan berita berjudul "Presiden Pilihan Indonesia”. Dalam berita, Seputar Indonesia menampilkan pidato Prabowo sebagai calon Presiden serta hasil survey Indonesia Research Center yang mempredikasi Probowo akan mengungguli Joko Widodo. Dukungan berbagai partai politik dan tokoh dan Ormas ditampilkan sebagai keunggulan Prabowo. Sementara Joko Widodo diberitakan didukung pedagang pasar, tanpa disertai pidato kampanye atau wawancara Joko Widodo. Melalui berita tersebut, Seputar Indonesia sedang mengonstruksi 
wacana yang memarjinalkan Jokowi. Pemarjinalan tersebut. dilakukan dengan penekanan bagaimana Jokowi diposisikan di dalam teks berita, dimana hasil survei IRC menyebutkan Prabowo lebih unggul dari Jokowi. Posisi seperti itu, menurut Rachmadi (1990) tidak hanya sekedar teknik jurnalistik, tetapi juga berkaitan dengan politik pemberitaan (Rachmadi, 1990: 6).

Pada pemberitaan dengan judul "Dugaan Pembocoran Materi Debat Capres", "Seputar Indonesia" mengabarkan adanya dugaan pembocoran materi Debat Calon Presiden yang menguntungkan pasangan calon presiden-walon wakil presiden Joko Widodo dan Jusuf Kalla. Meskipun berita ini dinilai tidak memiliki sumber berita yang jelas oleh Dewan Pers dan kurang memiliki dokumen yang kuat untuk mendukung tudingannya, strategi pengemasan pesan (framing strategies) dengan tema pembocoran materi debat calon presiden ini semakin memarjinalkan Jokowi, dan ditayangkan berulang-ulang dalam "Seputar Indonesia Sore" pada 11 Juni 2014, "Seputar Indonesia Malam" pada 11 Juni 2014 dan "Seputar Indonesia Pagi" pada 12 Juni 2014.

Pada pemberitaan edisi 11 Juni 2014, presenter berita Seputar Indonesia membahas tema mengenai headlines surat kabar Koran Sindo yang berjudul "Prabowo Paling Disukai". Seputar Indonesia melakukan strategi pengemasan pesan (framing strategies) dengan menampilkan Prabowo sebagai tokoh politik kelima di dunia yang paling banyak diberi tanda like (disukai) oleh pengguna media sosial Facebook. Presenter berita Michael Tjandra membahas Prabowo yang berada di posisi paling atas dalam halaman koran, bersanding dengan tokoh popular di dunia internasional lainnya seperti Barack Obama (Presiden AS), Narendra Modi (Perdana Menteri India), Mitt Romney (politikus dan mantan kandidat presiden AS), dan Arvind Kejriwal (politikus dan mantan kandidat perdana menteri India). Facebook menjadi medium Seputar Indonesia dalam mengonstruksi pesan dengan tujuan 
mempengaruhi opini publik. Titik sentral dalam konstruksi tersebut adalah opini yang dimanifestasikan dalam bahasa sebagaimana pembahasan pemberitaan dengan tema tingkat kesukaan publik terhadap figur Prabowo Subianto maupun sebagai pasangan Capres-Cawapres Prabowo-Hatta.

Pada konstruksi teks dimana pernyataan Wiranto mengenai Prabowo terkait kasus penculikan aktivis dan kerusuhan Mei 1998, keuntungan diperoleh Prabowo karena dianggap sebagai pihak yang dirugikan. "Klarifikasi Prabowo", demikian judul pemberitaan Seputar Indonesia pada tanggal 20 Juni 2014. Pada pemberitaan tersebut, Seputar Indonesia mengkonstruksi berita dimana Wiranto melakukan kampanye hitam 'menyerang' Prabowo dengan kasus penculikan aktivis, padahal Prabowo memiliki dokumen diberhentikan secara hormat. Pernyataan Wiranto mengenai Prabowo yang telah melanggar sumpah prajurit, menuai reaksi yang menentang Wiranto tetapi di lain pihak menjadi keuntungan bagi Prabowo yang dikesankan sebagai pihak yang dirugikan. Tim Prabowo menyatakan akan melaporkan pernyataan wiranto sebagai 'kampanye hitam' kepada Bawaslu. Praktik wacana ini dinilai kontraproduktif bagi kubu Jokowi dan menguntungkan kubu Prabowo.

\section{Kendali Politik dalam Redaksi Berita Televisi}

Breed (1955) dalam Social Control in The Newsroom mengatakan ruang redaksi bukanlah sebuah blackbox yang steril, tetapi ada suatu editorial policy atau kebijakan redaksional yang harus dipatuhi. Bahkan, pihak pemilik media mempunyai hak untuk menetapkan dan menerapkan secara paksa kebijakan perusahaan media tersebut. Akibat adanya tekanan pemilik media, proses penulisan berita menemui banyak konflik kepentingan. Para pengelola media senantiasa melakukan proses penyeleksian dalam menyajikan isi pesan dalam menjalankan fungsi-fungsinya. Materimateri yang dijadikan program berita maupun program hiburan, 
serta sosialisasi yang ditawarkan media, telah disaring terlebih dahulu. Menurut Dennis McQuail, media massa merupakan "Filter yang menyaring berbagai hal untuk diberi perhatian atau tidak. Isu atau informasi yang terpilih itu kemudian dikemas sedemikian rupa sehingga membentuk suatu konstruksi atau tampilan tertentu. Dengan demikian, khalayak tidak hanya dipilihkan tentang suatu hal yang menurut media layak mendapat perhatian, tetapi juga diarahkan untuk melihat hal tersebut dari sudut pandang tertentu", (Eriyanto, 2002: xi-xii).

Ideologi pemberitaan di media massa yang dibungkus dalam agenda kampanye pemilihan presiden merupakan bagian dari perubahan sosial yang kian cepat dan kian luas. Dalam buku Manufacturing Consent: The Political Economy of Mass Media, Herman dan Chomsky mengatakan mereka yang menguasai media biasanya juga mempunyai kepemilikan pada bidang bisnis dan memiliki kepentingan politik tertentu. Manajemen pemberitaan dalam newsroom RCTI yang menghasilkan program berita Seputar Indonesia memiliki kecenderungan tidak menganut asas independensi sebagai ideologi yang harus dipegang teguh karena kepentingan pemilik media begitu kuat mempengaruhi konstruksi teks dalam proses pembuatan berita. Dalam kasus di RCTI, divisi pemberitaan dilarang memproduksi konten yang merugikan kepentingan perusahaan atau pemilik media. RCTI adalah bagian dari MNC Group, dimana saham terbesarnya dimiliki oleh Hary Tanoesudibyo, aktivis Koalisi Merah Putih (KMP) pendukung Prabowo-Hatta.

Praktik wacana media juga tidak bisa dilepaskan dari kepentingan pemilik modal/pemilik media. Wacana adalah sebuah realitas yang telah diproses melalui dikonstruksi jurnalis menjadi berbentuk berita atau opini dalam media massa. Oleh karena itu, selain analisis terhadap teks, beberapa narasumber internal Seputar Indonesia, mengkonfirmasi hasil kajian mengenai praktik wacana 
(konsumsi teks) Seputar Indonesia. Terkait praktek wacana dan keberpihakan "Seputar Indonesia" dalam Pilpres 2014, jurnalis RCTI Raymond Rondonuwu mengakui bahwa "Seputar Indonesia" nampaknya berpihak pada Prabowo, dan sikap tersebut, dilakukan dengan melanggar Kode Etik Jurnalistik. "Seputar Indonesia" terkesan mendukung Prabowo dan mengkritik Joko Widodo tanpa memperhatikan Kode Etik Jurnalistik. Raymond meminta pimpinan redaksi untuk tidak memproduksi berita rivalitas Prabowo versus Jokowi dengan menggunakan narasumber twitter @triomacan karena khawatir pemberitan tidak obyektif. la memberi saran agar membuat berita yang berimbang dan tidak menyerang tanpa sumber berita yang jelas. Pertimbangan Raymond untuk tetap independen dan tidak menyerang salah satu pihak semata adalah alasan idealisme. Hal yang sama disampaikan jurnalis RCTI lainnya yang menolak untuk disebutkan identitasnya. la tidak memungkiri bahwa RCTI terkesan memihak kubu Prabowo, sehingga berita yang dibuat kurang mengedepankan sikap professionalisme dan kurang berimbang. Jurnalis RCTI ini mengakui adanya permintaan beragam angle berita yang harus memusatkan fokus pada kegagalan Jokowi, misalnya mengenai proyek mobil Esemka yang dinilai gagal dan murid-murid SMK yang kecewa karena dijanjikan setelah lulus akan mendapatkan pekerjaan ketiak menjadi walikota Solo. Angle berita lainnya adalah mengenai kegagalan menata kota Solo. Proyek Citywalk menjadi terbengkalai ketika Jokowi menjadi Gubernur DKI Jakarta, sehingga mengakibatkan sejumlah wilayah yang telah dialihfungsikan untuk pembangunan infrastruktur menjadi terbengkalai.

Dengan mengetahui bagaimana interaksi antara idealisme jurnalis dengan kepentingan pemilik media melalui studi kasus di RCTI pada masa Pemilu 2014 lalu kita bisa mendapatkan gambaran bagaimana kendali politik pemilik media bekerja mempengaruhi idealisme jurnalis dalam praktik jurnalistik di redaksi pemberitaan. Struktur organisasi "Seputar Indonesia", khususnya dalam tataran teknis redaksi antara Pemimpin Redaksi dan Produser Berita 
dimana ideologi pemilik modal 'secara tersamar' disampaikan, menyebabkan ruang keleluasaan individu untuk memilih menjadi berkurang. Hal ini menunjukkan bahwa hubungan kekuasaan antara pemilik modal, di satu pihak, dan kaum buruh di pihak lain melahirkan hegemoni pemilik modal. Relasi media dan relasi politik dalam pemilihan presiden memang pada kenyataannya tidak bisa menghindari adanya dukung-mendukung. Proses tersebut akan berlangsung secara otomatis karena konflik kepentingan pemilik modal yang sudah memiliki afiliasi politik tertentu kepada kandidat tertentu yang diusung oleh partai tertentu.

Kembali ke pertikaian Raymond Rondonuwu dan pemred RCTI. Pada akhirnya hasil kajian Dewan Pers menyatakan pemberitaan RCTI tentang "Dugaan Pembocoran Materi Debat Capres" telah melanggar Pasal 1 dan Pasal 3 Kode Etik Jurnalistik karena memuat berita yang tidak jelas sumbernya. Senada dengan argumen Raymond kepada manajemen pemberitaan RCTI, Dewan Pers menilai seharusnya RCTI melakukan verifikasi lebih dulu terhadap informasi tentang bocornya materi debat sebelum memuatnya atau sebelum melakukan konfirmasi dalam rangka memenuhi prinsip keberimbangan. Namun, pasca keputusan itu, Raymond memilih mundur dari redaksi "Seputar Indonesia". Demikian juga Lowell Bergman, ia memilih mundur dari CBS meskipun berhasil memperjuangkan penayangan penuh wawancara eksklusif Jeffrey Wigand di "60 minutes". Hasil liputannya berdampak besar bagi publik Amerika. Perusahaan rokok di Amerika harus mengeluarkan lebih dari 200 milyar dolar Amerika untuk menyelesaikan tuntutan hukum. Lowell memutuskan keluar dari CBS karena merasa tak ada lagi kebebasan pers. Press is free, for anyone who owns one, katanya. Pers bebas hanya dimiliki oleh mereka yang memiliki media.

Kita berharap, para jurnalis profesional yang masih bertahan bekerja di media massa terus berupaya untuk memiliki posisi tawar kepada pemilik media dalam memproduksi berita yang penting bagi 
publik di Indonesia. Amanat Undang-Undang Pers, Undang-Undang Penyiaran, P3SPS KPI dan Kode Etik Jurnalistik yang mengatur bahwa pers harus independen jangan sampai dikalahkan oleh dominasi kepentingan politik pemilik modal dan bisnisnya. Hak kebebasan penyiaran harus dibarengi dengan kewajiban terhadap masyarakat yang lebih luas yang melebihi kepentingan pribadi. Lembaga penyiaran swasta yang menggunakan frekuensi publik, harus memperkuat peran dalam memberikan pendidikan literasi kepada masyarakat. Tidak memanipulasi hak publik dengan menghalangi publik atas fakta-fakta obyektif dalam proses produksi berita. Idealisme tidak boleh dikalahkan oleh dominasi kepentingan ekonomi dan politik pemilik media.

\section{Referensi}

Aziz, A. (2003). Memahami fenomena sosial melalui studi kasus. Jakarta: PT. Rajagrafindo Persada.

Breed, W. (1955). Social control in the newsroom: A functional analysis. Social forces, 326-335.

Herman, E. S., \& Chomsky, N. (2010). Manufacturing consent: The political economy of the mass media. Random House.

Eriyanto, 2002. Analisis Framing: Konstruksi, Ideologi, dan Politik Media, Yogyakarta, Lkis

Hamad, I. (2004). Konstruksi realitas politik dalam media massa: Sebuah studi critical discourse analysis terhadap berita-berita politik. Yayasan Obor Indonesia.

McQuail, D. (1987). Mass Communication Theory (Teori Komunikasi Massa). Jakarta: Erlangga.

Rachmadi F, (1990). Perbandingan Sistem pers (Analisis Deskriptif Sistem Pers di berbagai negara, Penerbit PT Gramedia, Jakarta. 


\section{Profil Penulis}

Dani Setiadarma lahir di Tangerang, 29 Juli 1977. la menyelesaikan gelar master of corporate communication di Universitas Paramadina. Saat ini ia sedang menjalani program doctoral ilmu komunikasi di Universitas Indonesia. Ia memiliki pengalaman 15 tahun sebagai jurnalis di TRANS TV dan RCTI. Saat ini ia bekerja sebagai Head of Communication Department, Faculty of Business and Social Sciences, Dian Nusantara University. 